\title{
KEY FACTORS TO RESTORE CONFIDENCE IN UKRAINIAN BANKING SYSTEM
}

\author{
O. Shchurevych \\ Ivan Franko National University of Lviv \\ 79008, Lviv, Svobody Avenue, 18 \\ e-mail: oksana.shchurevych@lnu.edu.ua
}

\begin{abstract}
The research is dedicated to defining the confidence level in Ukrainian banking system. In order to define the level of confidence, the author of the research applied the following criteria: growth rates of deposits, maturity structure of deposits, dollarization of deposit portfolio, which allow to conduct a complex analysis of the confidence level in Ukrainian banking system. The researcher has identified factors that affect confidence and offered the means of confidence improvement in post-crisis conditions of banking business development.

Keywords: trust in banks, banking system, deposit portfolio, financial literacy.
\end{abstract}

The success of banking activity depends on the level of their client's trust. The reason is that for banks, in order to perform their main functions, it is necessary to attract free deposits. Individuals make decisions about opening deposits only if they completely trust the financial institution. Therefore, there is a direct relation between trust, volumes of deposits, increased lending, which has a great impact on economic growth and improving the overall well-being of the population.

The subject has been central to a number of scholars, which was caused by crisis phenomena in the banking system of Ukraine between 2014 and 2016. Such an active discussion of the issue of trust in banks among theoreticians and practicians has been caused primarily by the consequences it would have for the banking system and economic development. It is worth mentioning the works by K.M. Bazadze [2], A.V. Somyk [3, 4], V. S. Stoiko, and the pieces of research conducted by other rating agencies.

Despite an active discussion in the scientific environment about determining the level of trust in banking institutions, it should be noted that the banking system is actively developing, crisis trends are already in the past, and the banking sector is resuming operations after the crisis of the previous years. In these circumstances, there is an objective need to review the conditions and factors that affect the level of trust in banks, as well as finding optimal directions for its improvement.

The purpose of the article is to determine the level of trust in the banking system through systems of indicators, justification of factors of influence, and also giving of recommendations to raise its level.

It is a well-known thesis that money love silence. This leads to the conclusion that as soon as if there is even minimal panic among the population, respectively, the volume of

(C) O. Shchurevych, 2019 
deposits in banks are beginning to decline sharply, which is immediately reflected in the financial stability of the institution.

In general, the concept of "trust" is rather subjective. It is extremely difficult to quantify trust. National rating agencies conduct a population survey to determine the level of trust in the banking system.

Thus, InMind, which is supported by a US agency for International Development USAID and commissioned by the Deposit Guarantee Fund, found that, in 2015, 19\% of the survey respondents did not trust financial institutions while, in 2019, approximately $53 \%$ of respondents did not trust financial institutions. Trust in banks is approximately at the level of $20 \%$, but the percentage of those who fully trust banks or regulators of the financial sector is 3\% [6]. According to the Institute of Economics and Forecasting, as of June 2018, the number of people who do not trust banks is $69.6 \%$ NASU. The Ministry of Finance also conducts quarterly surveys about the most trusted banks. The interviewers also ask the respondents which of the 31 banks they would trust more than $200000 \mathrm{UAH}$. Thus, in September 2018, the most trusted banks were PrivatBank, Oshchadbank, and Megabank. Besides, they were asked the following questions: 1) Do you deposit with banks? 47\% answered "yes, regularly"; $32.4 \%$ answered "yes, from time to time"; 12,3 are not going to do this; $8.3 \%$ are not, and they never will be.

Approximately $36 \%$ of those polled place deposits with a bank to protect their savings from inflation. A little less (35\%) expect to multiply their savings [7].

Generally, depositors who choose banks to accommodate their savings are guided by the reliability of banks. Dragon Capital Investment Company, together with Business News Magazine, published the rating of the most reliable banks based on the following criteria: capital adequacy, liquidity, investor confidence, shareholder support, profitability, asset quality, etc.

On April 1st, 2019, according to the results of the study five of the most reliable banks are: Raiffeisen Bank Aval, Ukrsibbank, Citibank, Credit Agricole Bank, Ying Bank. State banks (Privatbank, Oshchadbank, and UkrEximbank) are ranked 7th, 8th and 9th, respectively [8].

Forinsurer, a journal that investigates insurance companies, rated the reliability of the banks according to which Credit Agricole Bank, Raiffeisen Bank Aval, Ukrsibbank, Oschadbank and UkrEximbank are the first five in the list. In terms of reliability for individuals, the leading positions are occupied by OshchadBank, UkrEximbank, Ukrgasbank, as they are state-owned, and deposits are fully guaranteed by the state [9].

According to the results of a sociological survey by the Razumkov Center on 01.03.2019, the rates of trust in banks and the NBU are the following: $36.7 \%$ and $31.56 \%$ do not trust banks at the regulator respectively. The numbers of those who rather do not trust are $38,1 \%$ and $36,6 \%$. Those who rather trust $-13.9 \%$ and $19.83 \%$. Those who completely trust $-1.6 \%$ and $1.5 \%[10]$.

According to a research conducted by USAID about trust to state and private banks, $3 \%$ and $6 \%$ fully trust, $17 \%$ and $29 \%$ are more likely to trust; $42 \%$ and $28 \%$ do not trust at all state and private banks.

Thus, it should be noted that, as a result of the crisis, political unstability, and unstable macroeconomic situation, the level of trust in financial institutions remains low.

A number of indicators were selected to assess the level of public confidence in banks. As we believe, most accurate ones include growth deposits, term structure of the deposit base, and share of dollarization of deposits. 
In order to carry out a comprehensive analysis of banks' resource base by section of borrowed funds, let us first consider the structure of household deposits in general (Fig. 1) and the growth rate of the deposit portfolio (Fig. 2).

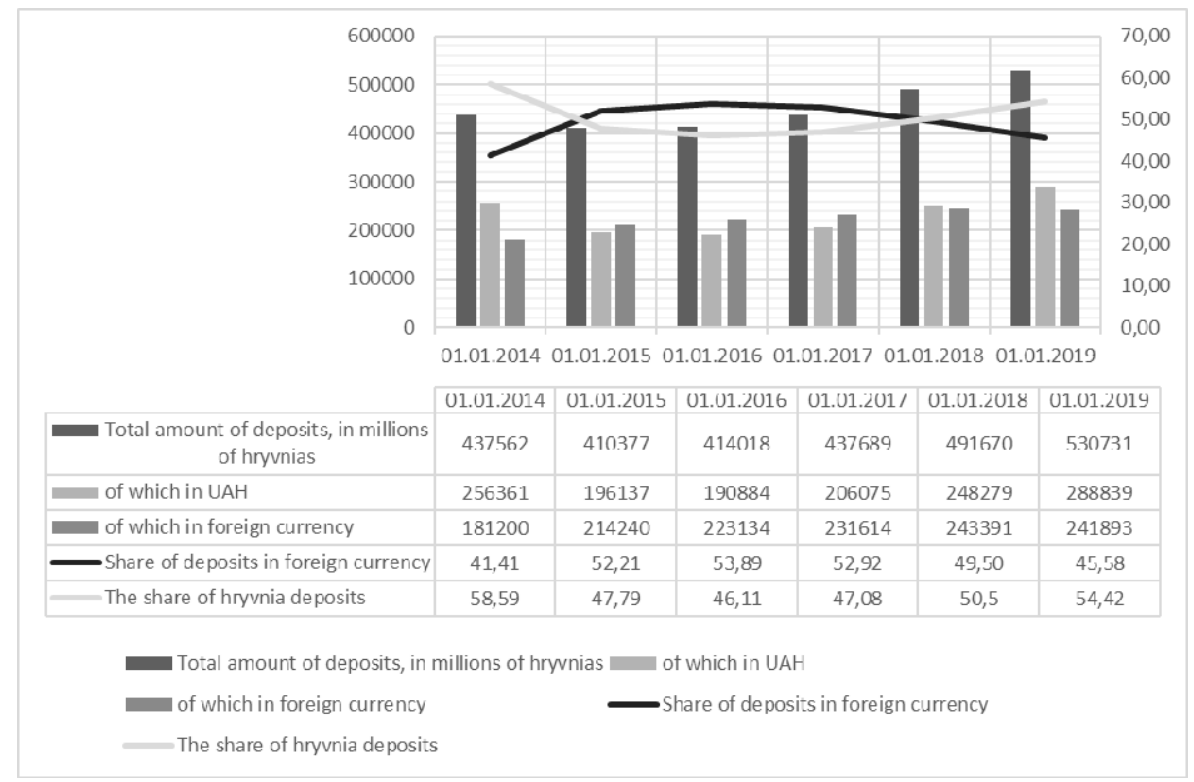

Fig. 1. Structure of the deposit portfolio of banks

Source: Developed by author based on NBU data

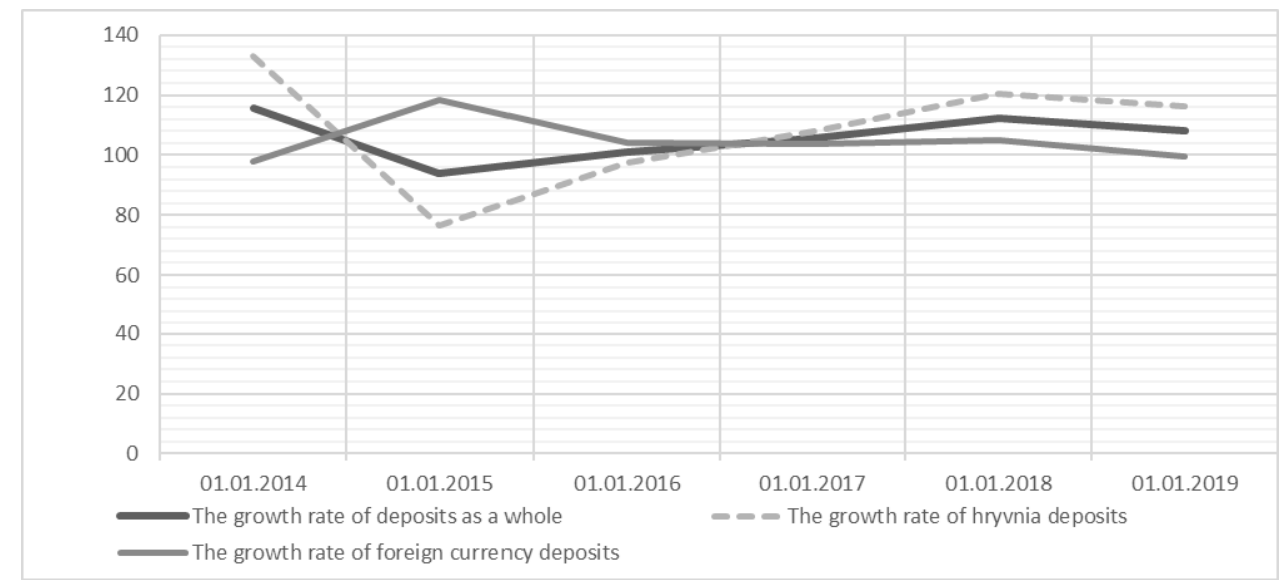

Fig. 2. The growth rate of deposits in the banking system of Ukraine during 2014-2019

Source: Developed by author based on NBU data

Retail deposits, as of 01.01.2014, were UAH 437562 million and increased by $15 \%$ as compared to the previous year (Fig. 1). During this period, there were crisis tendencies that have been caused by the accumulated problems of the banking sector during the previous 
periods, as well as the general macroeconomic and military situation. Starting from 2014, the National Bank of Ukraine used radical actions in the banking sector to reduce the negative the effects of the crisis, but they have had the opposite effect, thereby deepening this effect. This concerns the procedure for cleaning-up the banking sector that was conducted the NBU, and the use of flexible exchange rates. The consequences of these actions were significant devaluation of the hryvnia, as well as accelerated outflow of deposits. All in all, in 2014, depositors withdrew deposits for the following sums: 39.8 billion nationally currency and \$ 10 billion.

As of 01.01 .2015 , the growth rate of deposits was negative for hryvnia deposits, and for deposits in foreign currency, we see an increase of $18 \%$ only because of the need for exchange rates in UAH (Fig. 2). To reduce the outflow of deposits was a law, which came into force on May 2015, prohibited early withdrawal of term deposits, which, in turn, positively affected banks' liquidity.

Situation with deposits in 2016 is as follows: the total amount of deposits is UAH 414 018 million, of which UAH 190884 million in national currency. One can state that postcrisis recovery begins during this period. The gradual return of public confidence in banks started in 2017, which is reflected in the overall increase in national currency deposits. This trend continued into 2018 .

The currency component of the retail deposit portfolio determines the level of confidence in savings in hryvnias, as well as the volume of dollarization (Fig. 3).

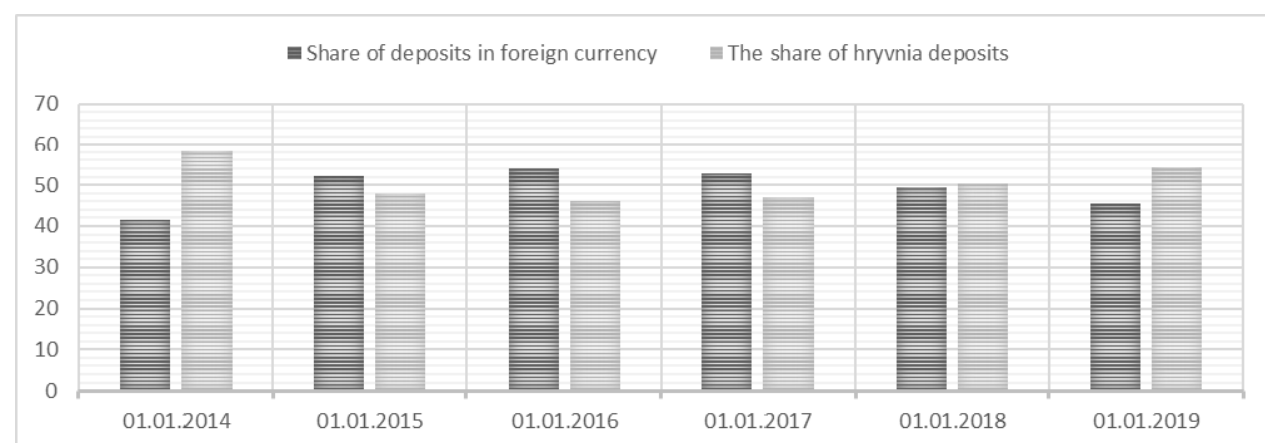

Fig. 3. Shares of hryvnia and foreign currency deposits in the structure of the deposit portfolio

Source: Developed by author based on NBU data

During the period under review (2014-2019), the share of foreign currency deposits ranged from $41.41 \%$ to $53.89 \%$ (Fig. 3). Starting from 2017 , it has been gradually decreasing, which is caused by low interest rates on foreign currency deposits. However, in general, such a high share of foreign currency deposits is a negative phenomenon and shows a low level of confidence in the national currency, which is a consequence of the devaluation of hryvnia almost three times in the previous periods and the desire of depositors to save their deposits from depreciation.

The following group of criteria shows the amount and share of individual deposits in terms of timeliness, which is indicative of confidence in the banking system (Fig. 4, Fig. 5). 


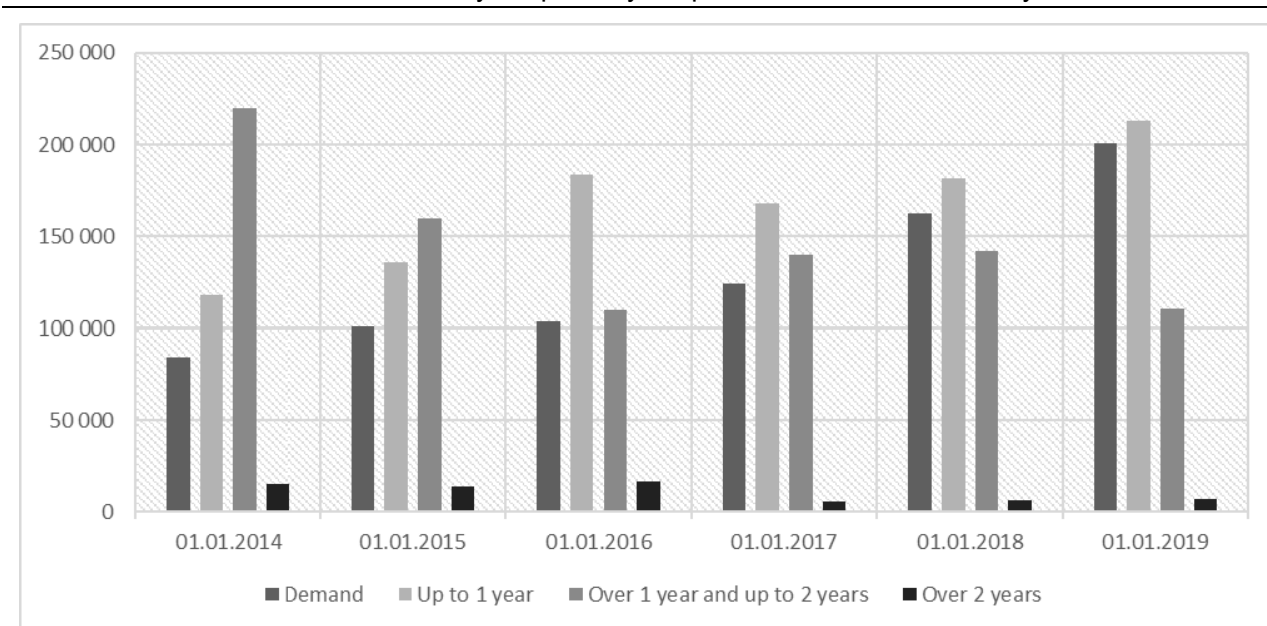

Fig. 4. The volume of deposits in the banking system by maturity

Source: Developed by author based on NBU data

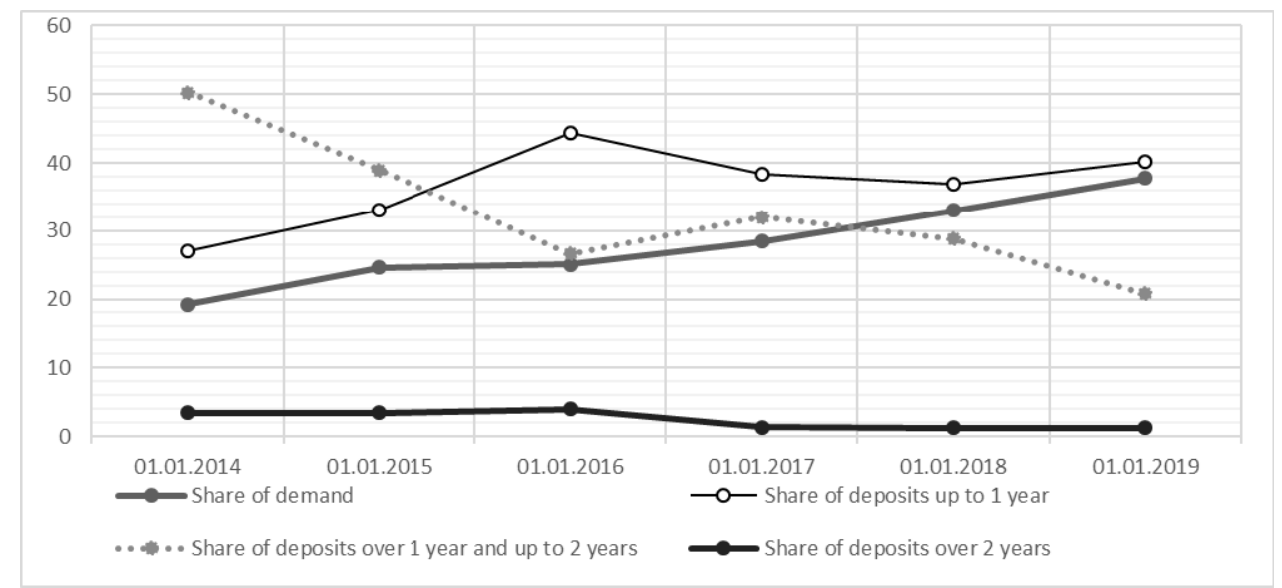

Fig. 5. Term structure of deposits in the banking system of Ukraine

Source: Developed by author based on NBU data

It is worth mentioning that the increase in demand deposits (Figure 4) is a negative phenomenon and indicates that these funds can be removed from the banking system at any time. The consequence is an increase in probability of the liquidity crisis. According to 2014 , the share of deposits is as follows: on 01.01 .2014 . $-19 \%$, on $01.01 .2015-25 \%$, on 01.01.2016. - $25 \%$, on 01.01.2017. - 28\%, on $01.01 .2018-33 \%$, on $01.01 .2019-38 \%$. This data reflects a threat to stability of the banking system.

The share of deposits up to 1 year during the analyzed period fluctuates between 27 and $44 \%$ (Fig. 5). On 01.01.2014. the share is $27 \%, 01.01 .2015$. - 33\%, $01.01 .2016-44 \%$, 01.01.2017 - 38\%, 01.01.2018 - 37\%, 01.01 .2019 - 40\%. 
According to the National Bank of Ukraine data shown in Fig. 4-5, the share of deposits from 1-2 years decreases, as well as more than 2 years. This is a consequence of banks' interest rate policy and is driven by mistrust.

Thus, one can conclude that short deposits, that is, demand up to 1 year prevail. This indicates a lack of long resources to lend to the real economy and possible liquidity gaps. In general, consumer behavior in the financial services market is determined by the following factors such as emotionality and trust, that is, it usually operates on the principle of irrationality. Therefore, taking this into consideration, it is important for banks to take all necessary measures to ensure that people's minds are positive.

As the banking system is two-tier, the factors of influence need to be considered in the context of two groups of entities and the credibility of each of them should be assessed. On the NBU's side, the importance of improving the effectiveness of monetary policy, maintaining the stability of the hryvnia exchange rate, implementation of measures to increase the financial literacy of the population, as well as the creation of a legislative framework for effective protection of consumer rights. Equally important are the periodic speeches of the NBU leadership regarding clarification of the situation in the currency, monetary market. It will form a favorable basis for understanding the nature of processes in the banking environment and will lay the groundwork for the gradual restoration of confidence.

The concept of "trust in the banking system" combines both psychological and behavioral aspects, which may have different effects on profitable activity of banks. On the one hand, it implies full trust between two entities - both customer to bank and bank to customer. During periods of exacerbation of crisis there was a situation where investors, panicking, withdrew their deposits in large amounts. In this case, the banks were hostage to the situation and suffered from significant losses. Therefore, it is crucial that you avoid such situations by maintaining trust in banking institutions and, above all, national currency.

The level of financial literacy of the population, consumer protection plays a key role in maintaining confidence in financial institutions. But customer awareness of financial services is not a panacea for increased confidence. First of all, it is necessary to create a favorable macroeconomic environment, to contribute to annual economic growth. This, in turn, will eventually lead to improving the financial well-being of the population, improving the standard of living they will have and the reverse effect will be increasing confidence in banks, the NBU, and other bodies power.

1. Офіційний сайт Національного банку України [Електронний ресурс]. - Режим доступу: http://www.bank.gov.ua/

2. Базадзе К. М. Відновлення довіри до банківської системи: міф чи реальність / К. М. Базадзе // Фінансовий простір. - 2015. - Вип. 1 (17). - С. 50-55

3. Сомик А. В. Підвищення довіри до банків в Україні / А. В. Сомик // Проблеми і перспективи розвитку банківської системи України. - 2014. - Вип. 38. - С. 250257.

4. Сомик А. В. Чинники довіри до банків в Україні / А. В. Сомик // Вісник Української академії банківської справи. - 2013. - Вип. 2 (35). - С. 37-42.

5. Стойка В. С. Можливості відновлення довіри до банківської системи України в сучасних умовах / В. С. Стойка // Науковий вісник Ужгородського університету. Серія Економіка. - 2017. - Вип. 1 (49). - С. 289-293. 
6. Більше половини українців не довіряють банкам [Електронний ресурс]. - Режим доступу: https://www.unian.ua/economics/finance 10144520-bilshe-polovini-ukrajincivne-doviryayut-bankam-doslidzhennya.html

7. Яким банкам довіряють вкладники [Електронний ресурс]. - Режим доступу: https://minfin.com.ua/ua/2018/09/06/34798850/

8. Топ-20 найнадійніших банків України [Електронний ресурс]. - Режим доступу: https://biz.nv.ua/ukr/finance/top-20-naynadiynishih-bankiv-ukrajini-reyting-nv50014747.html?prefer_lang=ukr

9. Рейтинг надійних банків України 2019 [Електронний ресурс]. - Режим доступу: https://forinsurer.com/rating-banks

10. Рівень довіри до суспільних інститутів та електоральні орієнтації громадян України [Електронний ресурс]. - Режим доступу: http://razumkov.org.ua/ napriamky/sotsiologichni-doslidzhennia/riven-doviry-do-suspilnykh-instytutiv-taelektoralni-oriientatsii-gromadian-ukrainy.

\section{References}

1. Ofitsiinyi sait Natsionalnoho banku Ukrainy [Official site of the National Bank of Ukraine]. www.bank.gov.ua. Retrieved from http://www.bank.gov.ua/ [in Ukrainian].

2. Bazadze, K. (2015). Vidnovlennia doviry do bankivskoi systemy: mif chy realnist [Restoration of trust in the banking system: myth or reality]. Finansovyi prostir Financial space, 1, 50-55 [in Ukrainian].

3. Somyk, A. (2014). Pidvyshchennia doviry do bankiv v Ukraini [Increasing trust in banks in Ukraine]. Problemy i perspektyvy rozvytku bankivskoi systemy Ukrainy Problems and prospects of development of the banking system of Ukraine, 38, 250-257 [in Ukrainian].

4. Somyk, A. (2013). Chynnyky doviry do bankiv v Ukraini [Factors of trust in banks in Ukraine]. Visnyk Ukrainskoi akademii bankivskoi spravy - Bulletin of the Ukrainian Academy of Banking, 2, 37-42 [in Ukrainian].

5. Stoika, V. (2017). Mozhlyvosti vidnovlennia doviry do bankivskoi systemy Ukrainy v suchasnykh umovakh [Possibilities of restoring confidence in the banking system of Ukraine in modern conditions]. Naukovyi visnyk Uzhhorodskoho universytetu. Seriia Ekonomika. - Scientific Bulletin of Uzhgorod University. Economy series, 1, 289-293 [in Ukrainian].

6. Bilshe polovyny ukraintsiv ne doviriaiut bankam [More than half of Ukrainians do not trust banks]. www.unian.ua. Retrieved from https://www.unian.ua/ economics/ finance/ 10144520-bilshe-polovini-ukrajinciv-ne-doviryayut-bankam-doslidzhennya.html [in Ukrainian].

7. Yakym bankam doviriaiut vkladnyky [Which banks are trusted by depositors]. minfin.com.ua. Retrieved from https://minfin.com.ua/ua/2018/09/06/34798850/ [in Ukrainian].

8. Top-20 nainadiinishykh bankiv Ukrainy [Top 20 most reliable banks in Ukraine]. biz.nv.ua. Retrieved from https://biz.nv.ua/ukr/finance/top-20-naynadiynishih-bankivukrajini-reyting-nv-50014747.html?prefer lang=ukr [in Ukrainian].

9. Reitynh nadiinykh bankiv Ukrainy $2019^{-}$[The rating of reliable banks of Ukraine 2019]. forinsurer.com. Retrieved from https://forinsurer.com/rating-banks [in Ukrainian].

10. Riven doviry do suspilnykh instytutiv ta elektoralni oriientatsii hromadian Ukrainy [Level of trust in public institutions and electoral orientations of citizens of Ukraine]. razumkov.org.ua. Retrieved from http://razumkov.org.ua/napriamky/sotsiologichnidoslidzhennia/riven-doviry-do-suspilnykh-instytutiv-ta-elektoralni-oriientatsiigromadian-ukrainy [in Ukrainian]. 


\section{КЛЮЧОВІ ФАКТОРИ ВІДНОВЛЕННЯ ДОВІРИ ДО БАНКІВСЬКОЇ СИСТЕМИ УКРАЇНИ \\ О. Щуревич}

Львівський національний університет імені Івана Франка

79008 м. Львів, проспект Свободи, 18

e-mail: oksana.shchurevych@lnu.edu.ua

Підтримання довіри у банківській системі України є ключовим фактором забезпечення стабільного розвитку банківського сектора. Рівнем довіри також визначається ефективність банківської діяльності та здатність виконувати свої функції повною мірою.

Загалом термін «довіра» є суб’єктивним та його складно кількісно виміряти. Споживачі фінансових послуг схильні діяти за принципом ірраціональності, оскільки їхня поведінка на ринку визначається такими чинниками як довіра та емоційність.

Дослідження рейтингових агентств дає підстави стверджувати, що рівень довіри до фінансових установ залишається низьким. Це $\epsilon$ наслідком кризових подій попередніх років, політичної нестабільності та несприятливої макроекономічної ситуації.

Для визначення рівня довіри обрано низку показників, а саме: темп зростання депозитів, структура депозитної бази, частка доларизації депозитного портфеля, що дає змогу провести комплексний аналіз визначення рівня довіри до банківської системи.

За результатами досліджень встановлено, що починаючи 32018 року відбувається зростання депозитів у банківському секторі. А це свідчить про те, що поступово відновлюється довіра до банківської системи.

У структурі депозитного портфеля частка депозитів в іноземній валюті $\epsilon$ значною, що є негативним явищем та відображає низький рівень довіри до національної валюти, що було викликано значною девальвацією гривні у попередні періоди.

Проаналізувавши строкову структуру депозитного портфеля, варто зазначити, що переважають депозити на вимогу та терміном до 1 року.

Виокремлено основні напрями зростання рівня довіри населення до банківської системи: необхідно підвищити рівень фінансової грамотності населення, застосовувати заходи для захисту прав споживачів фінансових послуг. Створення сприятливого макроекономічного середовище, що забезпечує щорічне економічне зростання, також має велике значення.

Ці заходи в майбутньому призведуть до зростання фінансового добробуту населення, поліпшення рівня життя та матимуть зворотний ефект - підвищення довіри як до банків, так і до НБУ, а також до інших органів влади .

Ключові слова: довіра до банківської системи, банківська система, депозитний портфель, фінансова грамотність. 